\title{
Analyzing the Impact of Sensory Marketing on Consumers: A Case Study of KFC
}

\author{
Roopchund Randhir \\ Aberyswyth University (Mauritius Branch Campus), Quartier Militaire, Mauritius \\ Khirodhur Latasha, Panyandee Tooraiven, Bappoo Monishan \\ Université des Mascareignes, Rose Hill, Mauritius
}

\begin{abstract}
Sensory marketing is a useful marketing application which gives companies a real opportunity to maximize product profitability. Consumers' eating habits keep changing everyday away from their regular meal, less time and more working hours have left people with the option to just pop in a restaurant or fast-food. The use of five senses in the marketing field helps to arouse customer's emotions and nowadays it is fundamental for the company to differentiate itself from its competitors. The study will seek to analyze the impact of sensory marketing of consumers with a particular reference to KFC. This study outline has a deep impact on understanding the impact of senses on marketing with particular reference to the Kentucky Fried Chicken in Mauritius. The present research shows that the different senses have an impact on consumer buying behaviour especially for KFC consumers. Consumers find the senses such as music to be relaxing and smell as stimulating. However, it should be mentioned that this research is limited to the sample size and also to the context of the study.
\end{abstract}

Keywords: sensory marketing, KFC, senses

Sensory marketing is widespread in marketing field and it may explain most of our purchasing decisions. It has an influence on the buying perception at new food court or restaurants emerging at every corner. Sensory marketing is used in different aspects: visual, auditory, olfactory, gustative, and tactile marketing. Sensory branding is a type of marketing which appeals to all the senses in relation to the brand. It uses the senses to relate with customers at an emotional level. Brands can falsify emotional associations in the customers' minds by appealing to their senses. A sensory experience is described as an individual's perception of goods or services or other essentials in a service process as an image that challenges the human mind and senses. Brakus, Schmitt, and Zarantonello (2009) differentiated among product experiences, shopping, and service experiences, as well as consumption experiences, concluding that all such experiences influence directly or indirectly on consumers.

Corresponding author: Roopchund Randhir, BSc, MBA, DipM ACIM, lecturer, Aberyswyth University (Mauritius Branch Campus), Quartier Militaire, Mauritius; research fields: customer relationship management, higher education.

Khirodhur Latasha, BSc (Hons) Management, Université des Mascareignes, Rose Hill, Mauritius; research field: sensory marketing.

Panyandee Tooraiven, BSc (Hons) Management, Université des Mascareignes, Rose Hill, Mauritius; research field: marketing management.

Bappoo Monishan, BSc (Hons) Management, Université des Mascareignes, Rose Hill, Mauritius; research field: sensory marketing. 
Schmitt (1999) proposed acting, feeling, relating, sensing, and thinking as customer experiences. Nowadays, more marketing specialists are willing to adopt this strategy resulting into great success to their business and it is difficult for a customer not to buy a product with this type of marketing. Sensory marketing is defined as a way of measuring and explaining consumer emotions as well as spotting and capitalizing on new market opportunities, and finally ensuring long-lasting product success.

\section{Literature Review}

\section{Emergence of Five Senses in the Marketing World}

Sensory marketing is based on the concept that we are most likely to form, memorise, and discover the mind when all five senses are involved. By going outside the traditional marketing media of sight and sound, brands can establish a stronger and longer-lasting emotional connection with consumers. Krishna (2010) explained sensory marketing as "marketing that engages the consumers' senses and affects their behaviours". Advertising is not what it used to be. Even though, we are adopting more and more marketing resources communicating with consumers.

Consumers with an urge for advertisement-free entertainment are growing. Snappier graphics, faster editing, more appealing confirmations or bigger and better discounts will no longer do it. Moreover, to be perfectly frank, the most distinctive proposal is not likely to hold water, something new is required. In the search for something new, we have to move right outside of today's advertising prototype. We have to go back to the basics and identify what actually charms human beings on an ordinary, everyday basis. If there is a sound, touch, taste, and smell element, you would probably be right in assuming that this is merely a pleasant coincidence. One may ask why these four senses have been neglected and left to their natural protective roles.

Almost our entire understanding of the world is experienced through our senses. Our senses are our connection to memory and can tap right into emotion. Bringing on the five senses has worked very well in emotionally connecting people to the rituals of faith.

Visual marketing (sight). Sight is the most used sense in marketing, as it is the most stimulated by the environment. The choice of colours and forms in the conception of a product, the layout of a point of sale, the realisation of promotion campaign are key factors of success (or failure), which are well understood by marketers. Colours and shapes are the first way of identification and differentiation. Many brands are associated to a specific colour, then it is memorised more easily by customers; Coca Cola is red, Kodak is yellow, and KFC are red and white. The company can be identified even though the customer did not see the name. According to memory retention studies, consumers are up to $78 \%$ more likely to remember a message printed in colour than that in black and white. In the food and beverage industry, the impact of colours is obvious and sharply defined.

The visual system is to modify light patterns into information, according to which people are capable of perceiving forms, colours, dimensions, movements, and distances between objects. Recent years showed that the way the product looks is not the only factor important for the consumers.

Furthermore, researchers have showed that sight is a dominant factor in creating brand awareness and in generating customer experience.

Olfactory marketing (smell). Smells trigger certain parts of the brain responsible for creating emotions and memories. The human nose can identify and remember as many as 10,000 scents and as much as 75 percent of our emotions are generated by what we smell. Out of all the senses, smell is the only one with a 
direct link to the brain. As Dr. John Medina explains in his bestseller Brain Rules. The most famous technique of olfactory marketing in the food industry is the use of artificial smells to appeal to customers in the street, subway, or supermarkets.

The best example can be Starbucks coffee, the coffee shop. They have started roasting coffee beans within the stores instead of outsourcing the process. This spreads the odour of beans in the environment thereby giving richer sensory experience.

Paradoxically, there are only few studies in this field, in comparison with researches on visuals or sonorous stimulus. Researches on the smells started these last 15 years, especially in the United States, so many questions are still unanswered.

However, the impact of smells on customers' behaviour has been definitely certified. First, researchers proved the positive impact of a smell on the evaluation of a product (Laird, 1935; Cox, 1969). According to Spangenberg, Crowley, and Henderson (1996b), a pleasant smell influences positively the evaluation of the customer on a point of sale (and some of its products), the intent of walk-through, of buying, as well as on the time spent inside (real and perceived). But the precise olfactory characteristics that could be at the origin of these influences are not yet determined.

Hirsch and Gay (1991) had noticed that women are more sensitive to smell than men. However, each sex does not have the reaction faced on the same smell: for instance, men stay longer than women in a shelf perfumed with spicy scent (Wall Street Journal, 1990), when women are more sensitive to shampoo smelling than men. The age of the customer modifies his perception, as according to Doty $(1984 ; 1985)$, the sense of smell breaks up as the person gets older.

In this way, there is also a difference between generations: People born before 1930 are more likely to call up natural smells, while youngest report more food or artificial smell (Hirsh, 1992). So the use of olfactory marketing can be interesting for a brand, provided that it knows how its target, to avoid a bad perception and then a negative impact.

Auditory marketing (sound). Sound has the power to influence our mood and sway our buying habits. To use sounds is known in advertising: To associate music to a message is a good way to make the consumer remember it. However, music is also important for sensory marketing users, since researches underlined the impact of music on behaviour, in a point of sale for instance. The effectiveness of a selling environment depends on its capacity to manage the subjectivity of the potential customer (Célier, 2004). When sound is directly linked to the product itself, consumers may interpret it as a sign of quality or familiarity. "Kellogg's TM takes full advantage of the sound element. Its Rice Krispies TM has the classic 'snap, crackle, pop', but did you know the crunch of the Kellogg's cornflake was carefully developed in sound labs?".

The power of music is in its capacity to contextualize the different articles and support emotional states and poses (Gumperz, 1977; DeNora, 1986). Music aims to put customer in a state of mind corresponding to the articles that are sold: Playing rock music in a guitar shop and the person will imagine himself playing with what could be his future purchase. Music can then, if connected to the product, be a way to act on the buying behaviour of the customer. It is also proved that high volume music in a bar will increase the consumption of the customers (North \& Hargreaves, 1996).

Studies have been made to find what kind of music fits the best with the different kinds of places: For instance, classical music will increase the quality sensation of a wine cellar (Areni \& Kim, 1993) or a tea house (North \& Hargreaves, 1996). But music can also act on the "crowd management", by influencing the time spent 
inside by the customer. For example, according to two studies from Roballey et al. (1985) and Milliman (1986), a fast-tempo music will push the customer to leave earlier. On the other hand, a slow music played at low volume will increase the time and the money spent inside. Same studies revealed also that clients will eat faster and consume less with a loud volume and fast-tempo music. Another research from Smith and Curnow (1966) revealed that in a point of sales, customer adopts his walk speed according to the tempo of the music. Music offers a wide range of possibility to the marketers to influence customers' behaviour and complete the atmosphere to create a coherent sales environment.

Tactile marketing (touch). Our skin has more than 4,000,000 sensory receptors that can be easily influenced through materials, weight, smoothness, and ease of the product. Sense of touch also plays a great part when it comes to packaging design, or even in some advertising campaigns. Packaging can give an enormous power on our brand awareness. It is a flawless method for getting close to consumer's unconsciousness, their perceptions, feelings, and tastes. The solid wish to pick up, touch, and test things is massive, and retailers count on that in their display strategies. Our hands are an important link between our brains and the world. The fact is that we humans, have more tactile nerve system in our little fingers alone than we do on our entire back.

In a restaurant, the weight of the cutleries, the softness of the napkins, the comfort of a chair can affect the perception the customers has of the atmosphere since, according to Rieunier (2002), the touch is one of the major determinants of the well-being sensation.

Gustative marketing (taste). People can sense five basic tastes: bitter, sour, savory, salty, and sweet. For all other aroma tastes, we must show gratitude to our sense of smell, for that is the one that gives flavor to our food. We can say that taste is the sense that merges all different senses together to create a complete brand experience, but is also related to emotional condition, so it can change mood and brand perception.

Thanks to scientific advancements, this sense is now highly mastered and exploited by producers in order to adapt their products to regional preferences: e.g. German consumer likes the sweet-salty mix, softly sour for the British one (Célier, 2004).

Recent studies aimed to understand better the mechanism of taste and explore the existing relations between, for instance, taste and colours. Thus, scientists now know that the four basic gustative sensations, sweet, sour, bitter, and salty, are respectively linked by consumers to the red, green, blue, and yellow colours (Célier, 2004). This might be important in the packaging design process of a product for instance.

In a promotional way, companies often use gustative marketing to convince customers, by making blind-tests (through comparatives advertisements for instance) or directly with sampling or free-tasting promotional operations. According to Rieunier (2002), such operations can be determinant in the food industry, as customers are more disposed to purchase a product that they already tasted and liked.

\section{Impact of Senses on Consumers}

It has been stated that consumers search for and buy emotional experiences around what has been bought and no longer buy products and services alone (Brembeck \& Ekström, 2004; Ratneshwar \& Mick, 2005). In this research, the sensory experience is related to the five human senses, despite their importance in generating customer value, sensory experiences, and the brand as an image. As such, there are six main elements: sight, sound, scent, touch, atmosphere, and taste associated with sensory marketing as discussed below.

Sight and its marketing impact. Empirical studies relating to sight impressions have been discussed by, for instance, Orth and Malkewitz (2008). The sense of sight is the most powerful one for detecting changes and 
differences in the environment and is the most used sense in perceiving goods or services. In studying sensory, emotional, and thinking capacity of the human brain, studies show that vision, for example, can interact with such senses as hearing, touch, and olfaction (Calvert \& Thesen, 2004). Another study has demonstrated that various techniques identify the five senses merging in the human brain, indicating that one sense can be affected by relations with other senses (Driver \& Noesselt, 2008). According to Henderson, Cote, Leong, and Schmitt (2003), quoted that the use of graphic information can make it easier for a product to stand out in the large amount of marketing messages, having a positive impact on the customers' consideration of a possible purchase (Kahn \& Deng, 2010). Further, visual sense has been shown to be of great significance when verbal material is absent, creating a perception of quality which has a direct impact on the building of a strong brand (Henderson et al., 2003). Furthermore, researchs have also deduced the visualised brands and other visual cues. It has been suggested that an unappealing product design might result in people searching for, expecting, and detecting problems, as well as observing details instead of ignoring small issues. A visually attractive product design may improve creativity in problem solving, as well as having an impact on mood (Norman, 2004). It can affect consumers in both a positive and a negative way without processing any other information (Norman, 2004). This is also emphasized by Messaris (1997) who argued that the sense of sight, beside the purpose of receiving attention, can elicit an emotional response towards a product and other things. A sight strategy stresses the meaning of such sensory expressions as colour, light, and theme, as well as graphics, exterior, and interior. All are underlined in picturing a brand's identity and values. The Finnish producer of mobile phones, Nokia, illustrates just this:

Nokia has chosen to design its phones with soft values in mind in order to appeal to human senses. The main rationale has been to move away from the hard values that technology conventionally stands for. This has been a way to make the mobile phones more user-friendly by giving each product an identity and soul. Nokia's big screen and soft buttons have been designed for this purpose and the ability to change the colour of phone suggests increased individualization.

Sound in marketing perception. Sound can be parted into two ways: wanted and unwanted sound, and Rossing, Moore, and Wheeler (2002) explained that there are more to the world of sound in the environment than music - namely noise. The authors elaborate this reasoning, and state that noise has been said to have an impact on communication as well as produce different psychological as well as physiological impact (Rossing et al., 2002). Sound has been since long in the field of marketing (Hultén, Broweus, van Dijk, \& Waxberg, 2008) and has been identified as a vital component that triggers and influences the consumer's mood, behaviour, and preferences (Bruner, 1990; M. I. Alpert, J. I. Alpert, \& Maltz, 2005). According to Kellaris and Kent (1992), music has the reputation to be the "shorthand of emotions" and has been used to provoke emotional responses in the consumer. With this in mind, music has been identified to play an important role in the lives of the consumers. Moreover, it is stated by Hul, Dube, and Chebat (1997) who explained that the individuals preference in music will affect if the advertising has a positive influence on the consumer or not, where Kellaris and Kent (1993) underlined that the chosen music will have an impact on how the message is perceived or processed by the consumer. Companies need to be aware of what type of music they are playing, using liked music with the aim to affect customer's general assessment of the store environment and the experience of it (Cameron \& Caza, 2004).

The American retailer Abercrombie \& Fitch demonstrates a sound strategy:

The sound at Abercrombie \& Fitch is expressed through famous songs which have been mixed to create the right atmosphere in the service landscape. A heavy bass represented in every song characterizes the firm's music. The music 
played is very loud and gives the impression of a night club. The songs are mixed to build up expectation that something more is under way. There are no gaps between the tracks and therefore the tempo level and sound pressure are constants in the store. Customers like the music and many dance in time to it. Employees also dance, which gives the relaxed feeling of party and of smell living it up.

Smell as a marketing element. Smell is an important element of our experience. We sniff the milk in the refrigerator before drinking it; we sniff if there is the single warning of smoke, and then behave accordingly. Our sense of smell guards us safe by serving us to choose fresh food and avoid rotten food. Each piece of fruit and cut of meat that finds its way into our shopping trolley has passed the sniff and feel test. Impulsively, we inspect for doubtful tears in the packaging and we wait, subconsciously for the clicking of the seal when we open a soda or a can of peanuts.

In this literature, as a cue or stimulus, scent can produce an effect in an individual's mind, affecting on the actual behaviour, without the person being aware of the process (Ward, Davies, \& Kooijman, 2003). In this concern, three different aspects of using scents have been emphasized in the research, the presence of a scent, its pleasantness, and its fit with environmental and service elements (Bone \& Ellen, 1999). In fact, a number of studies have demonstrated the positive effects of scents on buying intentions and store image (Parsons, 2009).

Moreover, research discloses that the existence of scent affects customer performance in terms of intentions to visit and return to a store (Bone \& Ellen, 1999) and also establishes a positive perception of a particular commercial environment (Chebat \& Michon, 2003). Various readings have considered the appeal of scents arising from an object, or a service associated with it being perceived as pleasant or unpleasant (Bone \& Ellen, 1999; Chebat \& Michon, 2003).

It is obvious from research that pleasant scents have positive properties on time spent in a store, the number of times products are inspected, in addition to, the total time devoted to product assessment (Morrin \& Ratneswhar, 2003; Schifferstein \& Verlegh, 1996; Spangenberg et al., 1996a). It is also assumed that, pleasant scents result in pleasant (unpleasant) affective consumer responses, in turn resulting in approach (avoidance) behaviour educated through the emotional response (Morrin, Krishna, \& Lwin, 2010).

Furthermore, research directs that arousing a pleasant scent is a cheap and effective way of improving customer shopping behaviour and creating increased cash outflow (Spangenberg et al., 1996a). On the whole, these effects may influence on consumer behaviour, leading them to spend more money, when they experience the pleasant smell of a retail atmosphere.

Agreement between scent and products improves product evaluations, for example, housecleaning solutions scented with lemon (Bone \& Ellen, 1999). It is apparent that consumers evaluate products more positively when the smell is considered typical for the product. On the other hand, it is also useful considering appropriateness between smell and the total service environment (Ward et al., 2003). The smell of Crayone color pens that make people recall the childhood life has in fact become a vital element in the company's brand strategy. Early in 2000, Crayone needed to shield their brand from the many unofficial competitors in Asia. This was challenging to the great extent. It was not easy to protect a color pen which draws generic colors. It is more difficult to do when the logo is barely familiar and the pens are parted from their packaging. All you can do is smell.

We examine the aroma of the original pen, Crayone artificially manufactured the smell and patented it. Today, the very characteristic smell that we so strongly associate with Crayone, is chemically coded and a crucial factor of the Crayone product. It is there to arouse the memory of generations of kids of the upcoming years, and above all, it is not possible to copy. 
A smell strategy is applied to permit a scent to become a component of a brand's identity and image. Scents add in creating memory pictures, a positive atmosphere, and well-being among both customers and employees. Eliminating unpleasant smells inside a car to make it more pleasing to get into and use was described in an interview with the Volvo marketing department in Gothenburg, Sweden:

We put a lot of effort into making the car smell good when one enters it. The new S80 and all of our cars are adapted for allergenic environments. The S80 is recommended by the Swedish Asthma and Allergy Association. When the car is opened with the hand control, the air is sucked out, as there is otherwise always an accumulation of the smell of plastic. This indicates the development work in this area, which is quite enormous.

Smell in relation to gender. According to Spangenberg et al. (1996a), they also noted that when "feminine scents" were used, sales of women clothes doubled; as did men's clothes when masculine scents were diffused. This underscores the importance of matching gender-preferred scents to the product. Both men and women browsed for longer and spent more money when a fragrance specific to their gender was used to scent the store atmosphere. Aroma preferences tend to be cultural and they can be generation-specific too, so the target market at each location will need to be pinpointed precisely.

Touch as a marketing concept. The tactile sense (or the sense of touch) is the first of our human senses to develop and the largest sensory organ (Gallace, Zeeden, Röder, \& Spence, 2010). Additionally, the tactile sense is considered as one of our most intimate senses, involving physical interaction with the skin, with the hands playing a vital part as our "principal source of input to the touch perceptual system" (Peck \& Childers, 2003a).

Research has established that consumers like to assess products and collect information about them through touch (McCabe \& Nowlis, 2003). It has also been proposed that it should be beneficial for retailers to let consumers touch and interact with products in retail settings (Grohmann, Spangenberg, \& Sprott, 2007). Researches have also shown that consumers desire store atmosphere that allow them to examine products tangibly (Krishna \& Morris, 2008) and to pick up, touch, and choose between products that are exposed (McCabe $\&$ Nowlis, 2003).

Touching products has been shown to exert a positive impact on shopper attitudes and behaviour, as well as on purchase intentions (Citrin et al., 2003; Peck \& Wiggins, 2006) and is associated with effective product placement in stores. Moreover, research has demonstrated that for some people, the effects of touch are stronger than for others (Peck \& Childers, 2003a). By using touch, a positive affective response might result in more positive attitudes toward a product (Peck \& Wiggins, 2006). In this context, touch means gaining information about the product and its characteristics, such as form, hardness, texture, or weight.

Peck and Wiggins (2006) drew attention to the touch that has possibly noteworthy consequences for store atmospherics, in the form of in-store and point-of-purchase displays. Researchers claim that displays can encourage touch and result in an interaction with products that customers would otherwise have ignored. This could increase instinct and unforeseen purchases (Peck \& Childers, 2008). Peck and Childers (2003b) showed how information gain through touching influences emotion and consumer. Haptic information, or by the hands, is important for the assessment of products that differ in terms of material properties related to texture, hardness, temperature, and weight. The authors develop and propose a conceptual framework to illustrate that salience of haptic information varies significantly across products, consumers, and situations. The authors conduct two tests to assess how these factors interact to impair or improve the achievement and practice of touching information or touch by hands. 
A touch strategy targets at consolidating the identity and image of a brand through a physical and psychological interaction with customers. Touching products makes it easier to recall them merely by looking at them. IKEA in Norway illuminates a touch strategy:

During the summer of 2007, the company let its customers stay the night. The aim was to create a touch experience of IKEA's beds, at the same time as the actual features of the bed were experienced during a night's sleep. The night stay was free, and the customers could choose between a basic dormitory, a family room, or a marriage chamber.

Atmosphere from marketing perception. In 1970's, Kotler claimed that the atmosphere of a place can be more dominant than the product itself, highlighting that the atmospherics can be regarded as the prime product. Store atmospherics are said to affect customers behaviour through its interaction with their perception (Puccinelli et al., 2009) and the thought of atmospherics is to create a positive experience that impacts the customer's perception, permitting them to imagine positive things, including the likelihood to try new things (Wagner \& Rudolph, 2010). Store atmospherics is defined as "an effort to design buying environments to produce specific emotional effects in the buyer that enhance his purchase probability" (Kotler, 1974) and concerns environmental cues that can have a possible effect on human behaviour as well their perception (Smith \& Burns, 1996). In connection to the above stated definition by Kotler (1974), Sharma and Stafford (2000) stated that design, ambiance, and social factors together make out atmospheric cues. The retail environment is, therefore, never unbiased, instead it is full of cues and various messages communicating with customers (Greenland \& McGoldrick, 1994). These cues, referred to as sensory cues are consequently of great significance in attracting the customer, creating an emotional relationship (Hultén, 2011). Since the store surroundings is becoming more and more fundamental with increased attention from both customers and store managers, the stores must be designed with different styling elements in a conscious way with the goal to appeal customers, affecting the buyers in different means (Turley \& Milliman, 2000; Solomon, Pierrehumbert, Matthews, Daniel, \& Friedlingstein, 2010).

This thinking is further developed by Summers and Hebert (2001) who argued that atmospherics express precise sensory qualities of a store environment that can be used to induce clear consumer responses. The atmospherics are directly linked with our senses, excluding taste, through which we will experience different sensory channels like colour, shape, scent, volume, or temperature (Kotler, 1974).

Store atmospherics are connected to amount of stimuli and different cues, where colour, scent, and music are included (Spangenberg et al., 1996b; Wagner \& Rudolph, 2010; Solomon et al., 2010), with an aim of impacting customers in a positive way through emotional responses at an unconscious stage (Donovan \& Rossiter, 1982).

Taste and sensory marketing. Taste is much more multifaceted than the experience of basic flavours on the tongue, it also encompasses our other senses to a larger degree than most people realise according to Professor Charles Spence. The taste sense is the most important and most developed of all senses. Very few of our taste preferences are biologically preset. Much rather they are linked with some sort of experience. Once a flavor or food is accepted, this can also influence the preference for and acceptance of new flavors or foods. If the sensory properties of a food are linked with negative sensations or reactions (nausea, vomiting during or after consumption), an aversion against this food develops that may remain for the rest of one's life. Nonetheless, positive sensations may also shape the preference for a food.

Taste is particularly significant when talking about food products - the actual taste of the product - sweet, sour, spicy, salty, fruity, and colorless - and our more general taste in food. In the case of manufactured foods, 
the major will depend very much on the next, which is, in turn, full of cultural tones-lifestyle, aspirations, childhood influences, and perceptions of the body. Understanding how our taste for food develops and what it says about us is, therefore, a feature of the growing discipline of cultural studies which worth examining by the marketing expert. It is about discovering the deeper layers of our disposition to food in general and cultural differences that might prepare food manufacturers to both marketing and research issues.

\section{Methodology}

According to Creswell (2003), methodology refers to the methods followed in collecting data and researching it on the lines of a developed discipline. The study is based mainly on surveys conducted through questionnaires submitted to approximately 100 random respondents who are in regular or frequent consumption at KFC and other restaurants. The questionnaire is designed to gain maximum perceptions of customers of how sensory marketing affects the consumption level of rational individuals and as such gain maximum information that can be useful for the management level of KFC restaurant. Moreover, preliminary content analysis of the open-ended questions was conducted using the software IBM SPSS Text Analytics for Surveys. Descriptive statistics and the chi-square test for uniform distribution were also used to analyze and compare data.

\section{Hypothesis}

$\mathrm{H}_{0}$ : There is no relationship between atmosphere and music and consumer buying behavior at KFC.

$\mathrm{H}_{1}$ : There is a relationship between atmosphere and music and consumer buying behavior at KFC.

$\mathrm{H}_{0}$ : There is no relationship between gender and scent in relation to consumer buying behavior at KFC.

$\mathrm{H}_{1}$ : There is a relationship between gender and scent in relation to consumer buying behavior at KFC.

\section{Analysis and Findings}

\section{Cross Tabulation}

Table 1

How Do You Feel When You Experience Music at KFC Restaurant? (Age Cross Tabulation)

\begin{tabular}{|c|c|c|c|c|c|c|}
\hline & & \multicolumn{4}{|c|}{ Age } & \multirow{2}{*}{-Total } \\
\hline & & $18-20$ & $21-23$ & $24-27$ & $28-30$ & \\
\hline \multirow{4}{*}{$\begin{array}{l}\text { How do you feel when you } \\
\text { experience music at KFC restaurant? }\end{array}$} & Relaxing & 8 & 44 & 10 & 1 & 63 \\
\hline & Exciting & 2 & 7 & 4 & 0 & 13 \\
\hline & Enjoying & 12 & 9 & 17 & 5 & 43 \\
\hline & Nothing & 1 & 11 & 2 & 0 & 14 \\
\hline Total & & 23 & 71 & 33 & 6 & 133 \\
\hline
\end{tabular}

According to Table 1 above, most of the youngsters found music to be relaxing, exciting, and enjoying compared to the ones who are slightly older that is 28-30. Music has a profound effect on youngsters; it can improve their moods and self-esteem or give them inspiration from role models. Music is something that every person has his or her own specific opinion. Different people have different taste. Similarly various types of music have many ways of leaving an impact on someone. It can be relaxing, exciting, soothing, enjoying, and many more. Associating music to a message is a good way to make the consumer remember it. However, music is also significant for sensory marketing users as researchers emphasized the impact of music on behaviour. 


\section{Correlation and Hypothesis Testing}

From Table 2, we can deduce that there is a weak correlation between smell (scent) and the motivation to choose the KFC restaurant. It is difficult in the way that perception of smells is different from a person to another, and there are plenty individual variants that marketers have to take into account. The first one is the sex of the person: Hirsch and Gay (1991) had noticed that women are more sensitive to smell than men. However, each sex does not have the reaction faced on the same smell: For instance, men stay longer than women in a shelf perfumed with spicy scent (Wall Street Journal, 1990), while women are more sensitive to shampoo smelling than men. The age of the customer modifies his perception, as according to Doty (1984; 1985), the sense of smell breaks up as the person gets older.

Table 2

The Relationship Among Gender and Scent and Buying Behaviour Correlations

\begin{tabular}{llll}
\hline & & Gender & $\begin{array}{l}\text { Does the smell (scent) of the restaurant motivate } \\
\text { you to choose the KFC restaurant without plan? }\end{array}$ \\
\hline & Pearson correlation & 1 & 0.050 \\
Gender & Sig. (2-tailed) & & 0.567 \\
& $\mathrm{~N}$ & 133 & 133 \\
$\begin{array}{l}\text { Does the smell (scent) of the } \\
\begin{array}{l}\text { restaurant motivate you to } \\
\text { choose the KFC restaurant }\end{array}\end{array}$ & Pearson correlation & 0.050 & 1 \\
without plan? & Sig. (2-tailed) & 0.567 & 133 \\
\hline
\end{tabular}

Table 3

How Do You Feel When You Experience Music at KFC Restaurant?

\begin{tabular}{llllll}
\hline & & Frequency & Percent (\%) & Valid percent (\%) & Cumulative percent (\%) \\
\hline \multirow{4}{*}{ Valid } & Relaxing & 63 & 47.0 & 47.4 & 47.4 \\
& Exciting & 13 & 9.7 & 9.8 & 57.1 \\
& Enjoying & 43 & 32.1 & 32.3 & 89.5 \\
& Nothing & 14 & 10.4 & 10.5 & 100.0 \\
Missing & Total & 133 & 99.3 & 100.0 & \\
Total & System & 1 & 0.7 & & \\
\hline
\end{tabular}

Experience music. From Table 3, it can be deducted that $47.0 \%$ found the atmosphere to be relaxing, 9.7\% found it exciting, $32.1 \%$ found it enjoying, and the last $10.4 \%$ found it as nothing. Figure 1 below shows that most of the participants strongly agreed that music is highly stimulating and exciting while buying at KFC, only a few explained that they felt nothing while listening to music.

Park and Young (1986) argued that music acted as a persuading signal. Music is used to arouse emotions corresponding with the symbolic meaning of the product; the likelihood of purchase is increased. When consumers enjoy the background music, they feel they have spent less time relative to the actual amount of time they have spent in the restaurant; if they dislike it, despite the short amount of time they have actually spent in the restaurant, they claim to have been there for much longer (Yalch \& Spangenberg, 2000; but see also Kellaris \& Kent, 1992).

Experience scent. From the below Table 4 and Figure 2, it can be said that $9.0 \%$ found it relaxing, $46.3 \%$ found it exciting, $31.3 \%$ found it enjoying, and $12.7 \%$ found it as nothing.

Seventy-five percent of emotions are generated by smell (S. Bell \& C. P. Bell, 2007). Consequently, smell 
symbolizes a direct line to feelings of happiness and hunger and is a sensory signal that cannot be turned off (Wilkie, 1995; Vlahos, 2007). Feldman (2009) demonstrated that people have strong abilities to easily remember odors associated with long forgotten events. Thus if an individual customer is not contented with an experience in a retail store, he or she may intensely remember it each time he or she sniffs a smell resembling which already occurred in his or her memory. The sense of smell is linked to pleasure and well-being and is closely associated to emotions and memories. As a scent can be administered and create an effect in a person's mind without him or her even paying attention to it, smell is "something that the customer cannot ignore".

Table 4

How Do You Feel When You Experience Scent at KFC Restaurant?

\begin{tabular}{llllll}
\hline & & Frequency & Percent (\%) & Valid percent (\%) & Cumulative percent (\%) \\
\hline \multirow{4}{*}{ Valid } & Relaxing & 12 & 9.0 & 9.0 & 9.0 \\
& Exciting & 62 & 46.3 & 46.6 & 55.6 \\
& Enjoying & 42 & 31.3 & 31.6 & 87.2 \\
& Nothing & 17 & 12.7 & 12.8 & 100.0 \\
Missing & Total & 133 & 99.3 & 100.0 & \\
Total & System & 1 & 0.7 & & \\
\hline
\end{tabular}

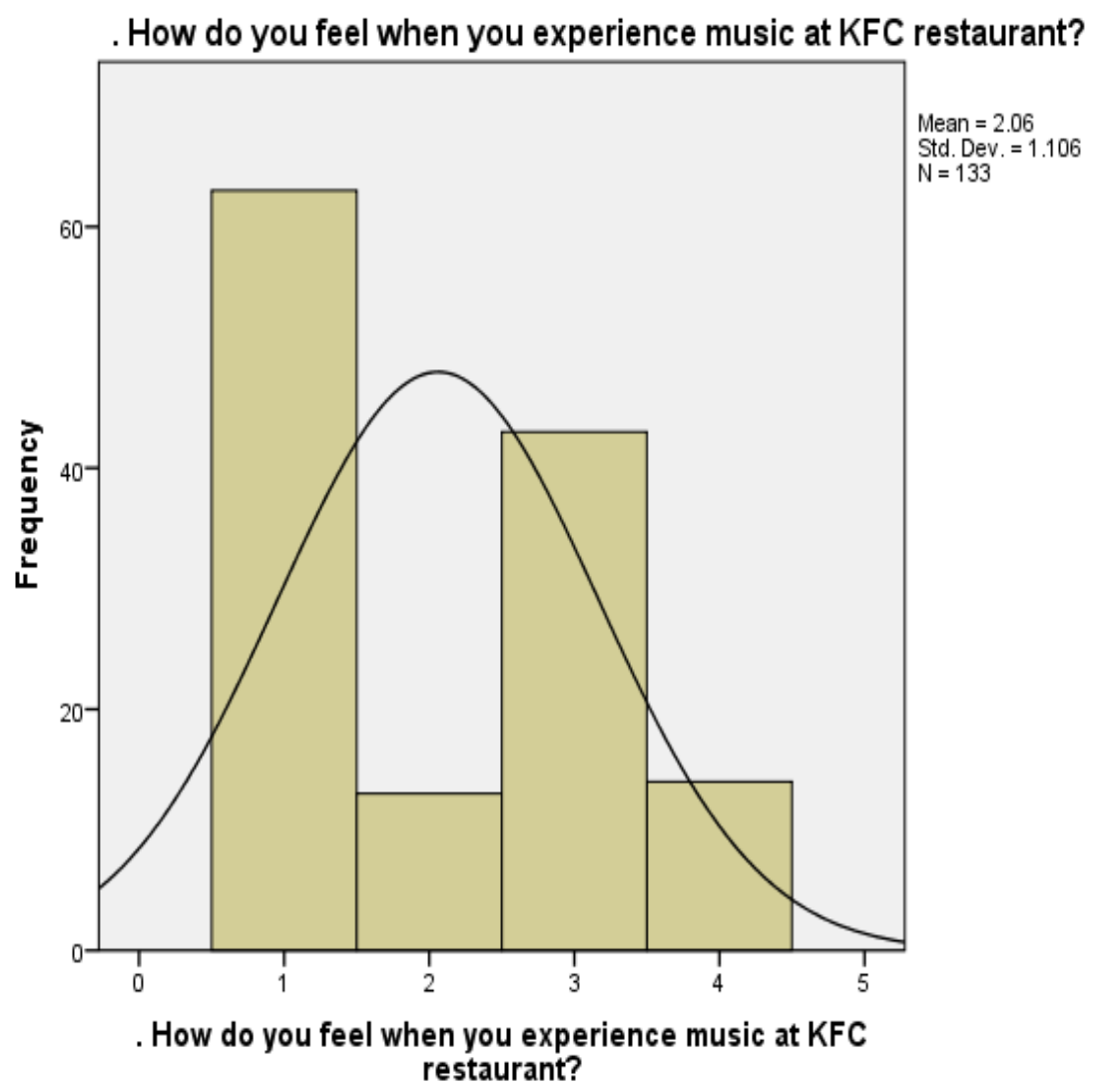

Figure 1. Experiencing music at KFC. 


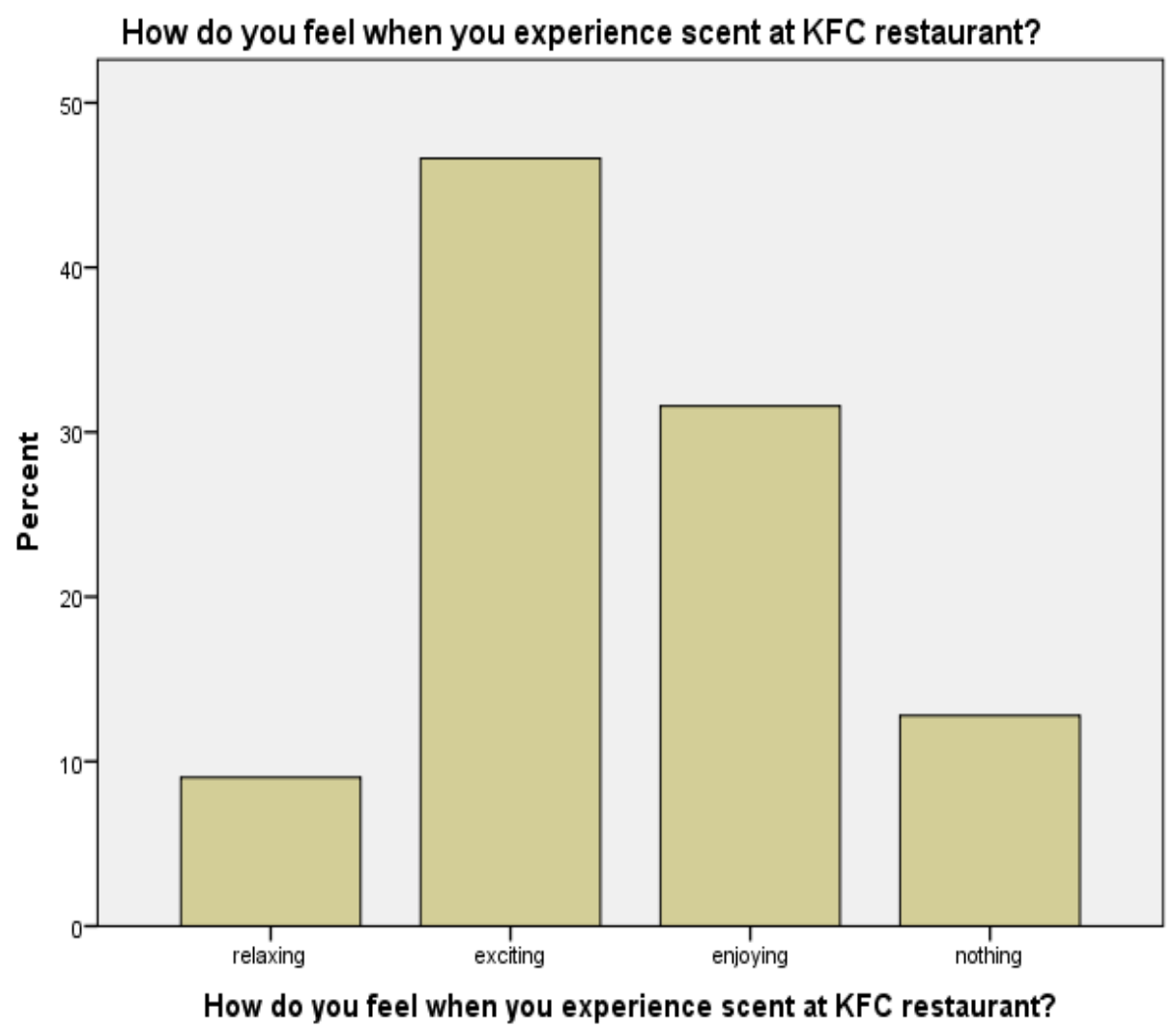

Figure 2. Experiencing scent at KFC.

\section{Conclusions}

Sensory Marketing, written by Dr. Bertil Hultén, Niklas Broweus, and Marcus van Dijk, delivers a new track for accepting how human senses construct an individual's experience; equally, it advises strategies on how a firm distinguishes and develops its own identity and unique product and branding through the involvement of human senses. Unlike typical marketing study, their work put the five senses in the front and center, emphasizing the importance of appealing each sense when marketing to customers. The five senses, smell, touch, taste, sight, and sound have a tremendous impact on how consumers purchase and experience products, services, and brands; nevertheless, academics and practitioners have long ignored their importance in marketing. Creatively, Sensory Marketing validates how the five human senses contribute to a firm's strategic marketing. Likewise, it suggests that a firm should consider the five human senses as a starting point in practice, consequently offering customers an absolute and unique experience.

A sensory manual covering the five human senses should be settled, in which sensorial strategies expressed through sensors, sensations, and sensory expressions as means, could be recognized in providing a brand's personal stamp to the customers. This can lead managers to build and establish successful multi-sensory brand-experience relationships, in disparity to more conservative and limited brand relationships.

\section{References}

Alpert, M. I., Alpert, J. I., \& Maltz, E. N. (2005). Purchase occasion influence on the role of music in advertising. Journal of Business Research, 58(3), 369-376. 
Areni, C. S., \& Kim, D. (1993). The influence of background music on shopping behavior: Classical versus top-forty music in a wine store. Advances in Consumer Research, 20, 336-340.

Bell, S., \& Bell, C. P. (2007). Future sense: Defining brands through scent. Retrieved from https://www.marketingsociety.com/ the-library/future-sense-defining-brands-through-scent

Bone, P. F., \& Ellen, P. S. (1999). Scents in the marketplace: Explaining a fraction of olfaction. Journal of Retailing, 75(2), 243-262.

Brakus, J. J., Schmitt, B. H., \& Zarantonello, L. (2009). Brand experience: What is it? How is it measured? Does it affect loyalty? Journal of Marketing, 73(3), 52-68.

Brembeck, H., \& Ekström, K. (2004). Elusive consumption. Oxford: Berg.

Broekemier, G., Marquardt, R., \& Gentry, J. W. (2008). An exploration of happy/sad and liked/disliked music effects on shopping intentions in a woman's clothing store service setting. Journal of Services Marketing, 22(1), 59-67.

Bruner, G. C. (1990). Music, mood, and marketing. Journal of Marketing, 54(4), 94-104. Retrieved from http://dx.doi.org/10.2307/ 1251762

Calvert, A., \& Thesen, T. (2004). Multisensory integration: Methodological approaches and emerging principles in the human brain. J Physiol Paris, 98(1-3), 191-205.

Cameron, K. S., \& Caza, A. (2004). Contributions to the discipline of positive organizational scholarship. American Behavioral Scientist, 47(6), 731-739.

Célier, P. (2004). Le marketing sensoriel (Sensorial marketing). Mohammedia ENSET School.

Chebat, J.-C., \& Michon, R. (2003). Impact of ambient odors on mall shoppers' emotions, cognition and spending: A test of competitive causal theories. Journal of Business Research, 56(7), 529-539.

Citrin, A. V., Stem Jr., D. E., Spangenberg, E. R., \& Clark, M. J. (2003). Consumer need for tactile input: An internet retailing challenge. Journal of Business Research, 56(11), 915-923.

Cox, D. F. (1969). The sorting rule model of the consumer product evaluation process, risk taking and information handling in consumer behavior. Boston, MA: Graduate School of Business Administration, Harvard University. Pp. 324-369.

Creswell, J. (2003). Research design: Qualitative, quantitative and mixed methods approaches (2nd ed.). Thousand Oaks, CA: SAGE Publications.

DeNora, T. (1986). How is extra musical meaning possible? Music as a place and space for work. Sociological Theory, 4(1), 84-94.

Donovan, R. J., \& Rossiter, J. R. (1982). Store atmosphere: An broader array of stores will provide a more diverse context in environment psychology approach. Journal of Retailing, 58, 34-57.

Doty, R., Newhouse, M. G., \& Azzalina, J. D. (1985). Internal consistency and short-term test-retest reliability of the University of Pennsylvania Smell Identification Test. Chem Senses, 10, 297-300.

Doty, R., Shaman, P., Applebaum, S. L., Giberson, R., Sikorsky L., \& Rosenberg, L. (1984). Smell identification ability: Changes with age. Science, 226, 1441-1443.

Driver, J., \& Noesselt, T. (2008). Multisensory interplay reveals cross modal influences on "sensory specific" brain regions, neural responses, and judgments. Neuron, 57(1), 11-23.

Feldman, R. S. (2009). Understanding psychology (9th ed.). New York: McGraw-Hill Higher Education.

Gallace, A., Zeeden, S., Röder, B., \& Spence, C. (2010). Lost in the move? Secondary task performance impairs tactile change detection on the body. Consciousness and Cognition, 19, 215-229.

Goldkuhl, L., \& Styvén, M. (2007). Sensing the scent of service success. European Journal of Marketing, 41(11/12), $1297-1305$.

Grayson, R. A. S., \& McNeill, L. S. (2009). Using atmospheric elements in service retailing: Understanding the bar environment. Journal of Services Marketing, 23(7), 517-527.

Greenland, S. J., \& McGoldrick, P. J. (1994). Atmospherics, attitudes and behaviour: Modelling the impact of designed space. The International Review of Retail, Distribution and Consumer Research, 4(1), 1-16.

Grohmann, B., Spangenberg, E. R., \& Sprott, D. E. (2007). The influence of tactile input on the evaluation of retail product offerings. Journal of Retailing, 83(2), 237-245.

Gumperz, J. J. (1977). Sociocultural knowledge in conversational inference. In M. Saville-Troike (Ed.), 28th annual round table monograph series on languages and linguistics. Washington, D.C.: Georgetown University Press.

Henderson, P. W., Cote, J. A., Leong, S. M., \& Schmitt, B. (2003). Building strong brands in Asia: Selecting the visual components of image to maximize brand strength. International Journal of Research in Marketing, 20(4), 297-313.

Hirsch, A. R. (1992). The sweet smell of success. Working paper. Smell and Taste Treatment and Research Foundation. 
Hirsch, A. R., \& Gay, S. E. (1991). The effect of ambient olfactory stimuli on the evaluation of a common consumer product. Proceedings from 13th Annual Meeting of Association for Chemoreception Sciences, April.

Hul, M. K., Dube, L., \& Chebat, J.-C. (1997). The impact of music on consumers' reactions to waiting for services. Journal of Retailing, 73(1), 87-104.

Hultén, B. (2011). Sensory marketing: The multi-sensory brand-experience concept. European Business Review, 23(3), $256-273$.

Hultén, B. (2012). Sensory cues and shoppers' touching behaviour: The case of IKEA. International Journal of Retail \& Distribution Management, 40(4), 273-289.

Hultén, B., Broweus, N., van Dijk, M., \& Waxberg, C. (2008). Sinnesmarknadsforing (Marketing of the senses). Malmo, Sweden: Liber.

Imram, N. (1999). The role of visual cues in consumer perception and acceptance of a food product. Nutrition \& Food Science, 99(5), 224-230.

Kahn, B., \& Deng, X. (2010). Effects on visual weight perceptions of product image locations on packaging. In A. Krishna (Ed.), Sensory marketing: Research on the sensuality of products (pp. 259-278). New York: Taylor and Francis Group.

Kellaris, J. J., \& Kent, R. J. (1992). The influence of music on consumers' temporal perceptions: Does time fly when you're having fun? Journal of Consumer Psychology, 1(4), 365-376.

Kellaris, J. J., \& Kent, R. J. (1993). An exploratory investigation of responses elicited by music varying in tempo, tonality, and texture. Journal of Consumer Psychology, 2(4), 381-401.

Kotler, P. (1974). Atmospherics as a marketing tool. Journal of Retailing, 49(4), 48-61.

Krishna, A. (2010). Sensory marketing: Research on the sensuality of products. New York: Routledge.

Krishna, A., \& Morrin, M. (2008). Does touch affect taste? The perceptual transfer of product container haptic cues. The Journal of Consumer Research, 34, 807-818.

Laird, D. A. (1935). How the consumer estimates quality by subconscious sensory impressions: With special reference to the role of smell. Journal of Applied Psychology, 16, 241-246.

Lindstrom, M. (2005). Broad sensory branding. Journal of Product \& Brand Management, 14(2), 84-87.

McCabe, D., \& Nowlis, S. (2003). The effect of examining actual products or product descriptions on consumer preference. Journal of Consumer Psychology, 13(4), 431-439.

Messaris, P. (1997). Visual persuasion: The role of images in advertising. Thousand Oaks, CA: Sage.

Milliman, R. E. (1986). Using background music to affect the behavior of supermarket shoppers. Journal of Marketing, 46(3), 86-91.

Morrin, M., \& Ratneshwar, S. (2003). Does it make sense to use scents to enhance brand memory? Journal of Marketing Research, 40(1), 10-25.

Morrin, M., Krishna, A., \& Lwin, M. (2010). Retroactive interference from scent cues and the effect on product recall. Journal of Consumer Psychology, 21(3), 354-361.

Norman, D. A. (2004). Emotional design: Why we love (or hate) everyday things. New York: Basic Books.

North, A. C., \& Hargreaves, D. J. (1996). The effects of music on responses to a dining area. Journal of Environmental Psychology, 16(1), 55-64.

Orth, U. R., \& Malkewitz, K. (2008). The sense of sight and perception. England: Burnley.

Park, C. W., \& Young, S. M. (1986). Consumer response to television commercials: The impact of involvement and background music on brand attitude formation. Journal of Marketing Research, 23(1), 11-24.

Parsons, G. (2009). Use of scent in a naturally odourless store. International Journal of Retail \& Distribution Management, 37(5), 440-452.

Peck, J., \& Childers, T. L. (2003a). Individual differences in haptic information processing: The "need for touch" scale. The Journal of Consumer Research, 30(3), 430-442.

Peck, J., \& Childers, T. L. (2003b). To have and to hold: The influence of haptic information on product judgments. Journal of Marketing, 67(2), 35-48.

Peck, J., \& Childers, T. L. (2008). If it tastes, smells, sounds, and feels like a duck, then it must be a ...: Effects of sensory factors on consumer behaviors. In C. P. Haugtvedt, P. M. Herr, and F. R. Kardes (Eds.), Handbook of consumer psychology (pp. 193-219). Florence, KY: Psychology Press.

Peck, J., \& Wiggins, J. (2006). It just feels good: Customers' affective response to touch and its influence on persuasion. Journal of Marketing, 70(4), 56-69.

Puccinelli, N. M., Goodstein, R. C., Grewal, D., Price, R., Raghubir, P., \& Stewart, D. (2009). Customer experience management in retailing: Understanding the buying process. Journal of Retailing, 85(1), 15-30. 
Ratneshwar, S., \& Mick, D. (2005). Inside consumption. London: Routledge.

Rieunier, S. (2000). L'influence de la musique sur le comportement du consommateur (Influence of music on the behaviour of consumers). Doctoral thesis, Université Paris Daupphine.

Rieunier, S. (2002). Le marketing sensoriel du point de vente (Sensorial marketing strategies). Applied Research in Marketing, 17, $40-45$.

Roballey, T. C., McGreevy, C., Rongo, R. R., Schwantes, M. L., Steger, P. J., Wininger, M. A., \& Gardner, E. B. (1985). The effect of music on eating behavior. Bulletin of the Psychonomic Society, 23(3), 221-222.

Rossing, T., Moore, R., \& Wheeler, P. (2002). The science of sound. San Francisco: Addison-Wesley.

Schifferstein, H. N. J., \& Verlegh, P. W. J. (1996). The role of congruency and pleasantness in odor-induced taste enhancement. Acta Psychologica, 94(1), 87-105.

Schmitt, B. H. (1999). Experiential marketing. New York, NY: Free Press.

Sharma, A., \& Stafford, T. F. (2000). The effect of retail atmosphere on customer's perceptions of salespeople and customer persuasion: An empirical investigation. Journal of Business Research, 49(2), 183-191.

Smith, P. C., \& Curnow, R. (1966). "Arousal hypothesis" and the effects of music on purchasing behaviour. Journal of Applied Psychology, 50(3), 255-256.

Smith, P., \& Burns, D. J. (1996). Atmospherics and retail environments: The case of the "power aisle". International Journal of Retail \& Distribution Management, 24(1), 7-14.

Solomon, S., Pierrehumbert, R. T., Matthews, D., Daniel, J. S., \& Friedlingstein, P. (2010). Atmospheric composition, irreversible climate change, and mitigation policy. Retrieved from http://geosci.uchicago.edu/ rtp1/papers/WCRPAnthropocene2012.pdf

Spandenberg, E. R., Crowley, A. E., \& Henderson, P. (1996a). Improving the store environment: Do olfactory cues affect evaluations and behaviors? Journal of Marketing, 60(2), 67-80.

Spangenberg, E. R., Crowley, A. E., \& Henderson, P. (1996b). Améliorer l'environnement du magasin: Les signaux olfactifs affectent-ils les évaluations et les comportements (Improving the retail environment: The olfactory effects on consumer buying behaviour)? Recherche et Applications en Marketing (Research and Applications in Marketing), 11(4), 71-92.

Summers, T. A., \& Hebert, P. R. (2001). Shedding some light on store atmospherics: Influence of illumination on consumer behavior. Journal of Business Research, 54(2), 145-150.

Turley, L. W., \& Milliman, R. E. (2000). Atmospheric effects on shopping behaviour: A review of the experimental evidence. Journal of Business Research, 49(2), 193-211.

Ugolini, M. M., Rossato, C., \& Baccarani, C. (2014). A five-senses perspective to quality in hospitals. The TQM Journal, 26(3), 284-299.

Vlahos, J. (2007, September 9). Scent and sensibility. The New York Times.

Wagner, T., \& Rudolph, T. (2010). Towards a hierarchical theory of shopping motivation. Journal of Retailing and Consumer Services, 17(5), 415-429.

Wall Street Journal. (1990, January 9). Scents that encourage buying couldn’t smell sweeter to stores. P. B5.

Ward, P., Davies, B. J., \& Kooijman, D. (2003). Ambient smell and the retail environment: Relating olfaction research to consumer behavior. Journal of Business \& Management, 9(3), 289-302.

Wilkie, M. (1995). Scent of a market. American Demographics, 17(8), 40-47.

Yalch, R. F., \& Spangenberg, E. R. (2000). The effects of music in a retail setting on real and perceived shopping times. Journal of Business Research, 49(2), 139-147.

Yu, C. P. (2011). Sensory marketing. Managing Service Quality: An International Journal, 21(5), 568-570. 